\title{
POSSIBILITIES OF INTRODUCING ICT TOOLS IN INFORMATION SOCIETY OF HIGH LEVEL ECOLOGY UNDERSTANDING
}

\author{
Krzysztof PYTEL
}

\begin{abstract}
The article introduces results of a survey whose principles were to know the opinion and the understanding of electronic learning. In the era of computers, the most important problem is the degradation of the environment. Therefore, very important environmental education could be accomplished in various forms. The aim of this paper is to acquaint about e-learning and analysis of the survey on e-learning, one of the tools that can be used in environmental education. The paper describes environmental education and presents the environmental knowledge of Poles. There have been a review of selected teaching methods that can be used in environmental education.
\end{abstract}

Key words: ecology, ICT, e-learning.

\section{MOŻLIWOŚCI WYKORZYSTANIA NARZĘDZI INFORMATYCZNYCH DO KSZTAŁTOWANIA SPOŁECZEŃSTWA INFORMACYJNEGO O WYSOKIM POZIOMIE ŚWIADOMOŚCI EKOLOGICZNEJ}

Resumé: $W$ artykule opisano wybrane wyniki i przedstawiono analize ankiety, której celem byto poznanie opinii $i$ stopnia znajomości nauczania na odlegtość. $W$ erze komputerów naglacym problemem jest degradacja środowiska. Dlatego też ważna jest edukacja ekologiczna, która przejawia się $w$ różnych formach. Celem publikacji jest przybliżenie wiadomości na temat nauczania elektronicznego oraz analiza wyników ankiety na temat e-learning, jednego $z$ narzędzi informatycznych, który można wykorzystać w edukacji ekologicznej. W artykule opisano edukację ekologiczna oraz przedstawiono świadomość ekologiczna Polaków w świetle wcześniejszych badań. Dokonano też przegladu wybranych metod nauczania, które sa wykorzystywane $w$ edukacji ekologicznej.

Klićcová slova: ekologia, ICT, e-learning.

\section{Wstęp}

Świat ery informacji zapomina o środowisku, w którym żyje i rozwija się. Stale rozwijają się techniki przekazywania wiedzy, a komunikacja międzyludzka będąc jednym z najważniejszych czynników pozwalających na poruszanie się $\mathrm{w}$ społeczeństwie zmienia swoją postać. Kiedyś najprostszym i najwygodniejszym sposobem porozumiewania się między ludźmi była mowa, dzięki której wyrażano swoje zdanie, obrazowano emocje i nawiązywano interakcje, a człowiek komunikował się na odległość przez telegraf czy telefon. Postęp techniczny w dziedzinie komunikacji wykreował nowe sposoby nawiązywania kontaktów, łatwiejsze, szybsze, wydajniejsze i tańsze. Dużo osób często i chętnie korzysta $\mathrm{z}$ nowych środków komunikacji, popularnością cieszą się komunikatory internetowe, poczta e-mail, telefonia internetowa czy portale społecznościowe. Systematyczny postęp i rozwój $\mathrm{w}$ dziedzinie komunikacji internetowej jest konieczny i potrzebny, ponieważ tradycyjne formy komunikacji zmieniają się w nowoczesne. Ewoluują również sposoby przekazywania wiedzy. Nauczanie za pośrednictwem mediów elektronicznych, podobnie jak nauczanie tradycyjne ma na celu przekazanie wiedzy. Bezpośrednie nauczanie osób uczestniczących w zajęciach ulega ewolucji w przekazywanie wiedzy w sposób pośredni za pomocą mediów elektronicznych. Dzisiaj jeszcze trudno wybrać metodę nauczania, która jest najbardziej skuteczna, gdyż zarówno nauczanie tradycyjne jak też nauczanie $\mathrm{z}$ wykorzystaniem metod komputerowych ma swoje wady i zalety.

Rozwój edukacji na odległość w Polsce ma szansę rozwoju, gdyż potrzeba sprostania wyzwaniom ery informacyjnej wymusza korzystanie $\mathrm{z}$ najnowszych rozwiązań techniki w każdej aktywności człowieka. Edukacja najbliższych lat to być może hybryda nauczania elektronicznego i tradycyjnego. Metody elearning będą wspierały a nie zastępowały nauczanie tradycyjne a technologia informacyjna będąc elementem życia młodego pokolenia 
wymusi wśród tutorów sprawne posługiwanie się najnowszymi metodami komunikacji, przekazywania wiedzy i informacji. Przyszłość edukacji elektronicznej jest pewna, jednakże droga jej rozwoju może ewoluować.

\section{Edukacja a świadomość ekologiczna}

Edukacja ekologiczna to działania ukierunkowane na przekazywanie i upowszechnianie wiedzy o ochronie i kształtowaniu środowiska. Edukacja ekologiczna przybliża ludziom problemy środowiska ich życia i pokazuje główne problemy świata. Umiejętnie realizowana wpływa na przekonania, nawyki i postępowanie młodego człowieka, który włącza się w identyfikowanie i przezwyciężanie problemów środowiskowych. Edukacja ekologiczna dotyka każdej cząstki życia człowieka kładąc nacisk zarówno na rozwijanie umiejętności praktycznego działania jak i na nabywanie wiedzy teoretycznej ucznia. Dzięki niej uczniowie zdobywają wiedzę użyteczną niemal w każdej problemowej sytuacji życiowej, w której należy opowiedzieć się za konkretnym działaniem wpływającym na środowisko życia i pracy. Edukacja ekologiczna obejmuje szereg działań, które umiejętnie przeprowadzone docierają do świadomości młodego człowieka, pogłębiają jego wiedzę, pobudzają w nim zrozumienie otaczającego go świata, rozbudzają zainteresowanie regułami rządzącymi przyrodą, rodzą odpowiedzialność za każdą aktywność a jednocześnie popychają do działania w kierunku pozostawienia środowiska niczym nie nienaruszonego dla przyszłych pokoleń. Edukacja wywołuje zmiany w życiu i przyzwyczajeniach młodego człowieka, wprowadza $\mathrm{w}$ tajniki coraz bardziej złożonej codzienności, a kontynuowana na wyższych etapach edukacji pokazuje stopień skomplikowania otaczającego świata.

Edukacja środowiskowa dotyczy nie tylko młodego pokolenia, dotyczy również dorosłych. Przyjmuje ona formę edukacji formalnej zakończonej świadectwem bądź edukacji ekologicznej nieformalnej, w której nie uzyskuje się żądnych dyplomów ani certyfikatów.

Edukacja ekologiczna dotyczy wszystkich na Ziemi i realizuje zadania wychowawcze. Główny jej cel to uwrażliwienie, a nie tylko zwracanie uwagi na niebezpieczeństwa dotyczące zagrożeń dla środowiska. Celem edukacji ekologicznej jest takie profilowanie wiadomości o funkcjonowaniu środowiska i przyczynach jego degradacji, aby uczniowie sami potrafili wynajdować metody jego ochrony. Edukacja ekologiczna to również ocena i kształtowanie umiejętności przewidywania konsekwencji własnego postępowania, szczególnie w zakresie ochrony środowiska naturalnego. Uczniowie uczą się szacunku i umiejętności zgodnego współżycia $\mathrm{z}$ naturą oraz nabywają emocjonalny stosunek do środowiska.

Świadomość ekologiczna będąc zestawieniem wiedzy i wrażliwości ekologicznej oraz postaw prośrodowiskowych może być indywidualna lub zbiorowa. W Polsce zostało przeprowadzonych szereg badań, których celem było określenie świadomości ekologicznej społeczeństwa. $\mathrm{Na}$ podstawie ogólnopolskich badań, które odbyły się w 2000 [1] i 2008 [4] roku można wysnuć wspólne wnioski. Ankietowani dostrzegają poprawę stanu otaczającego ich środowiska naturalnego w stosunku do lat wcześniejszych. Respondenci są świadomi roli człowieka w realizacji działań w zakresie ekologii i kształtowania środowiska. Badania wskazują na różnice pomiędzy oświadczeniami a rzeczywistym postępowaniem i zachowaniami Polaków, którzy coraz mniej interesują się problemami ekologicznymi. Ankietowani mając świadomość, że swoim działaniem przyczyniają się do zmiany stanu środowiska, w codziennym postępowaniu nie podejmują zbyt wielu działań proekologicznych. Wśród ankietowanych rodzi się zwątpienie w działania prośrodowiskowe. Jedyne pobudki do podejmowania działań proekologicznych są związane $\mathrm{z}$ troską o życie i zdrowie najbliższej rodziny oraz przyszłych pokoleń. Wyniki ankiety pokazują, że im wyższe wykształcenie i większa wiedza ekologiczna, tym częściej są podejmowania działania proekologiczne. Najwyższą świadomość ekologiczną mają osoby w wieku produkcyjnym, najniższą najmłodsi i osoby starsze. Osoby młode mogą zostać oczywiście wyedukowane w ramach edukacji formalnej, natomiast dla osób starszych pozostaje edukacja nieformalna. Analizując wyniki badań nasuwa się wniosek o konieczności rozwijania i promowania międzygeneracyjnej edukacji ekologicznej, która jest potrzebna niezależnie od formy jej realizacji. Szereg osób wiedzę ekologiczną czerpią głownie ze środków masowego przekazu bądź posiada ją jeszcze $\mathrm{z}$ okresu swojej edukacji formalnej.

3 Możliwości wykorzystania metod nauki elektronicznej w edukacji proekologicznej 
Istnieje wiele metod wspomagających nauczanie ekologii i wprowadzania $\mathrm{w}$ treści środowiskowe. Sa one wykorzystywane w nauczaniu formalnym bądź nieformalnym. Te metody to przykładowo warsztaty ekologiczne, zielone szkoły, edukacyjne ścieżki dydaktyczne, spektakle ekologiczne czy warsztaty o tematyce ekologicznej. W edukacji formalnej korzysta się tylko z wybranych metod, spośród których kilka przedstawiono poniżej.

Ścieżki edukacyjne będące zestawem treści i umiejętności o znaczeniu wychowawczym i poznawczym sa realizowane $w$ ramach nauczania szeregu bloków przedmiotowych. Zostały one wprowadzone do polskich szkół, jako efekt reformy systemu edukacji w 1999 roku i wciąż funkcjonują na II i III etapie edukacyjnym. Dyrektor i nauczyciele biorąc odpowiedzialność za realizację ścieżek edukacyjnych kształcą wśród uczniów szereg umiejętności według jednego $\mathrm{z}$ trzech modeli nauczania: linearnego, rozbieżnego i modelu przepływowego, które są realizowane wokół wybranej tematyki.

Z kolei warsztaty ekologiczne to forma zajęć aktywizująca uczniów. Warsztaty ekologiczne będąc prowadzonymi w szkole lub w terenie, mają na celu podniesienie świadomości ekologicznej oraz uwrażliwienie na problemy ochrony środowiska. Nabyte przez uczestników umiejętności stają się przydatne $\mathrm{w}$ życiu codziennym, a kontakty nawiązane $\mathrm{w}$ trakcie warsztatów przyczyniają się do wzrostu integracji w zespołach.

Zielone szkoły będące śródrocznymi, kilkudniowymi wyjazdami uczniów pod opieką nauczycieli w ciekawe pod względem przyrodniczym bądź kulturowym miejsca angażują uczniów w zajęcia tematyczne związane $\mathrm{z}$ edukacyjnym celem wyjazdu Cele edukacyjne zielonej szkoły zależą od tematu wiodącego i układu zajęć.

Wszystkie wymienione metody cechowały się bezpośrednim kontaktem nauczyciela z uczniem. Są jednak inne metody wspomagające przekazywanie treści prośrodowiskowych, którymi są zajęcia e-learning, ulotki, czasopisma, audycje radiowe, czy telewizyjne programy popularnonaukowe.

Realizacja zajęć w formie elektronicznej wymusza u nauczyciela wybór jednej z technik przekazywania wiedzy: zajęcia mieszane lub w pełni elektroniczne. Zajęcia mieszane są wspierane zazwyczaj Internetem, jako medium przekazania materiałów dydaktycznych. Zajęcia takie wprowadzają nowe wartości do tradycyjnego sposobu nauczania poprzez wzbogacone form przekazu. Dodatkowe wykorzystanie platformy e-learning umożliwia stosowanie wiedzy $\mathrm{w}$ praktyce i testowanie stopnia opanowania materiału poprzez liczne ćwiczenia i zadania proponowane i weryfikowane przez tutora.

Zajęcia w pełni elektroniczne odbywają się w całości na platformie edukacyjnej i mogą być realizowane, jako zajęcia asynchroniczne bądź synchroniczne, zależnie od interakcji pomiędzy nauczycielem a uczniem.

Zajęcia oferujące bardzo rozbudowane treści, mogą być tworzone ściśle według potrzeb ucznia bądź dla nieokreślonej grupy odbiorców, uczniów, studentów, kursantów, młodszych i starszych.

Jedną z metod nauczania ekologii jest kurs elearning zaprojektowany przy wykorzystaniu platformy e-learning i szeregu programów komputerowych wspomagających dydaktykę. Badając potrzebę wprowadzania nowoczesnych technik e-learning na grunt edukacji ekologicznej przeprowadzono badania ankietowe, których celem było poznanie opinii o znajomości nauczania na odległość. Ankieta składała się z 20 pytań, zbudowana była $\mathrm{z}$ pytań jednokrotnego i wielokrotnego wyboru. Badanie było anonimowe $i$ polegało na wypełnieniu kwestionariusza. Badaniu poddano 115 osób, wśród których było 50 kobiet $(43,48 \%)$ i 65 mężczyzn (56,52\%). Ponad 40\% ankietowanych zamieszkiwało miasta liczące powyżej 100 tysięcy mieszkańców, 36,5\% to mieszkańcy wsi, natomiast $22,6 \%$ to osoby zamieszkujące miasta do 100 tysięcy osób. Najliczniejszą grupą, która brała udział w badaniu stanowili respondenci w wieku od 21 do 30 lat (76,51\%), głównie studenci. Nieliczną grupę tworzą osoby w pozostałych przedziałach wiekowych (Rysunek 1).

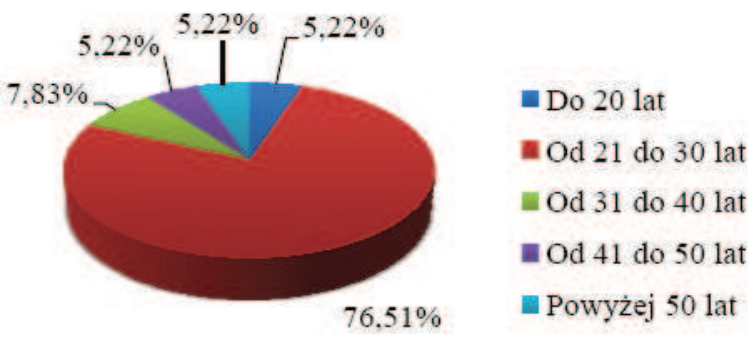

Rysunek 1: Wiek ankietowanych.

W artykule przedstawiono odpowiedzi ankietowanych na wybrane pytania. 
Obecnie Internet w Polsce jest powszechny i ogólnodostępny, tylko $6,09 \%$ respondentów z niego nie korzysta. Najczęściej Internet jest wykorzystywany do wyszukiwania informacji $(88,70 \%)$, do poczty e-mail $(79,13 \%)$, do zdobywania wiedzy $(73,91 \%)$ i komunikacji $(70,43 \%)$. Prawie połowa badanych wykorzystuje Internet do uczestnictwa $\mathrm{w}$ forach dyskusyjnych. Nieliczna grupa badanych podaje jeszcze inne wykorzystania Internetu (Rysunek 2).

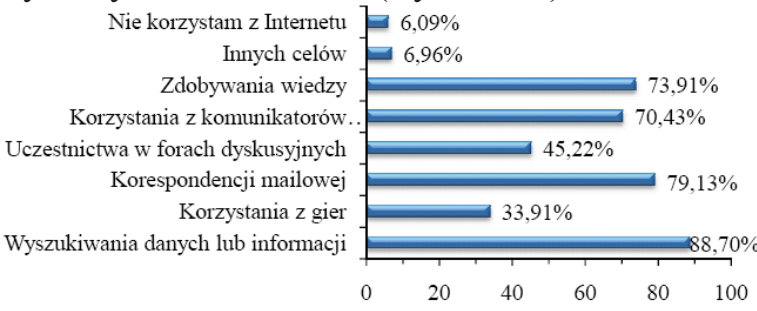

Rysunek 2: Wykorzystanie Internetu w opinii respondentów.

\begin{tabular}{|c|c|c|c|c|c|c|c|}
\hline & & Pracuję & Uczẹ siẹ & $\begin{array}{c}\text { Pracuje i } \\
\text { uczę się }\end{array}$ & $\begin{array}{r}\text { Jestem osoba } \\
\text { bezrobotną }\end{array}$ & $\begin{array}{c}\text { Jestem na } \\
\text { emeryturze/rencie }\end{array}$ & \\
\hline \multirow{2}{*}{ Do 20 lat } & TAK & 0 & 4 & 1 & 0 & 0 & 5 \\
\hline & NIE & 0 & 0 & 0 & 1 & 0 & 1 \\
\hline \multirow{2}{*}{ Od 21 do 30 lat } & TAK & 4 & 41 & 34 & 0 & 0 & 79 \\
\hline & NIE & 5 & 1 & 2 & 1 & 0 & 9 \\
\hline \multirow{2}{*}{ Od 31 do 40 lat } & TAK & 2 & 0 & 2 & 0 & 0 & 4 \\
\hline & NIE & 5 & 0 & 0 & 0 & 0 & 5 \\
\hline \multirow{2}{*}{ Od 41 do 50 lat } & TAK & 2 & 0 & 0 & 0 & 0 & 2 \\
\hline & NIE & 4 & 0 & 0 & 0 & 0 & 4 \\
\hline \multirow{2}{*}{ Powyżej 50 lat } & TAK & 2 & 0 & 0 & 0 & 0 & 2 \\
\hline & NIE & 1 & 0 & 0 & 0 & 3 & 4 \\
\hline & & 25 & 46 & 39 & 2 & 3 & 115 \\
\hline
\end{tabular}

Rysunek 3: Znajomość terminu e-learning $w$ opinii respondentów.

$\mathrm{Na}$ podstawie analizy wyników znajomości terminu e-learning można stwierdzić, że jest on powszechnie znany (Rysunek 3). Aż 80\% ankietowanych deklaruje znajomość pojęcia nauki elektronicznej, spośród których $65 \%$ to osoby uczące się lub jednocześnie uczące się i pracujące. Można przypuszczać, że głównie są to studenci.

\begin{tabular}{|c|c|c|c|c|}
\cline { 2 - 5 } \multicolumn{1}{c|}{} & Tradycyjny & E-learning & Mieszany & \multicolumn{1}{c|}{} \\
\hline Do 20 lat & 2 & 0 & 4 & 6 \\
\hline Od 21 lat do 30 lat & 38 & 3 & 47 & $\mathbf{8 8}$ \\
\hline Od 31 lat do 40 lat & 5 & 0 & 4 & 9 \\
\hline Od 41 lat do 50 lat & 2 & 1 & 3 & 6 \\
\hline Powyżej 50 lat & 4 & 1 & 1 & 6 \\
\hline & $\mathbf{5 1}$ & $\mathbf{5}$ & $\mathbf{5 9}$ & $\mathbf{1 1 5}$ \\
\hline
\end{tabular}

Rysunek 4: Skuteczność nauczania w opinii respondentów.

Około $45 \%$ badanych uważa za najbardziej efektywny tradycyjny sposób nauczania (Rysunek 4), natomiast połowa ankietowanych opowiada się za mieszanym sposobem nauczania. Niewielka liczba (4,35\%) ankietowanych opowiada się za nauczaniem tylko za pomocą metod e-learning. Największą grupę badanych stanowią osoby w wieku od 21 lat do 30 lat, których głosy podzieliły się prawie po połowie między nauczaniem tradycyjnym a blended learning ze wskazaniem na komplementarność obydwóch zupełnie różnych środowisk nauczania - tradycyjnego i komputerowego.

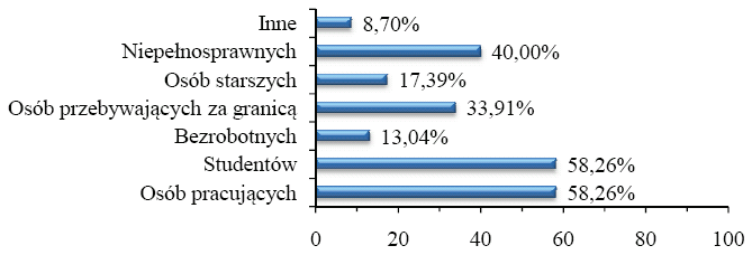

Rysunek 5: Adresowanie technik e-learning w opinii respondentów.

Około $60 \%$ badanych uważa, że e-learning jest skierowany głównie do studentów i osób pracujących (Rysunek 5). Według 40\% ankietowanych nauczanie na odległość jest skierowane do osób niepełnosprawnych. Natomiast według 33,91\% respondentów, e-learning jest doskonale dostosowany do osób przebywających za granicą. Niewielka grupa badanych uważa, że e-learning jest skierowany do osób starszych oraz bezrobotnych. Jako inna możliwość ankietowani wskazywali najczęściej, że e-learning jest skierowany do wszystkich grup społecznych. Analizując odpowiedzi na powyższe pytanie można wysnuć wniosek, że większość ankietowanych poprzez e-learning rozumie jedynie distance learning.

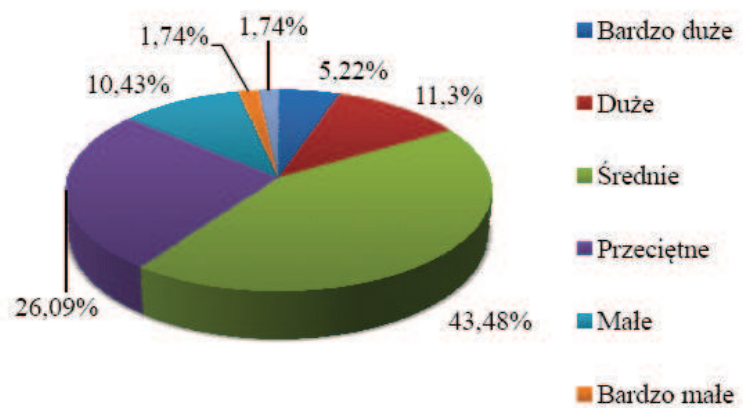

Rysunek 6: Zapotrzebowanie na e-learning w opinii respondentów.

Ponad 3/4 respondentów uważa, że w Polsce jest mniejsze lub większe zapotrzebowania na naukę zdalną, jak interpretowany jest e-learning (Rysunek 6).

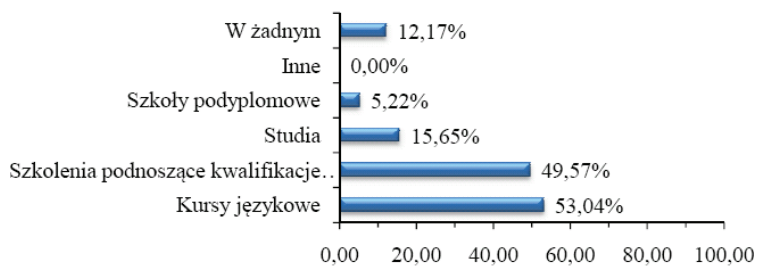


Rysunek 7: Zapotrzebowanie na tematyke szkoleń e-learning $w$ opinii respondentów.

Analizując zapotrzebowanie na kursy elektroniczne (Rysunek 7) zauważymy, iż ponad połowa badanych osób najchętniej wzięłaby udział w kursach językowych, czy też w szkoleniach podnoszących kwalifikacje zawodowe.

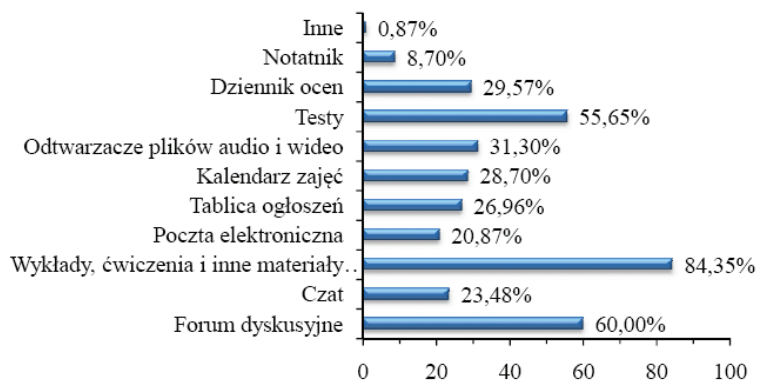

Rysunek 8: Zawartość systemu e-learning w opinii respondentów.

Kolejne pytanie dotyczyło dostępności wybranych funkcjonalności systemu e-learning (Rysunek 8). Elementy, jakie powinny być dostępne w ramach kursów e-learning to według $84,35 \%$ ankietowanych wykłady, ćwiczenia i materiały dydaktyczne. Ponad połowa respondentów uważa za ważne testy $\mathrm{i}$ fora dyskusyjne. Około 1/3 ankietowanych traktuje informacje organizacyjne za istotny element systemu zdalnego nauczania.

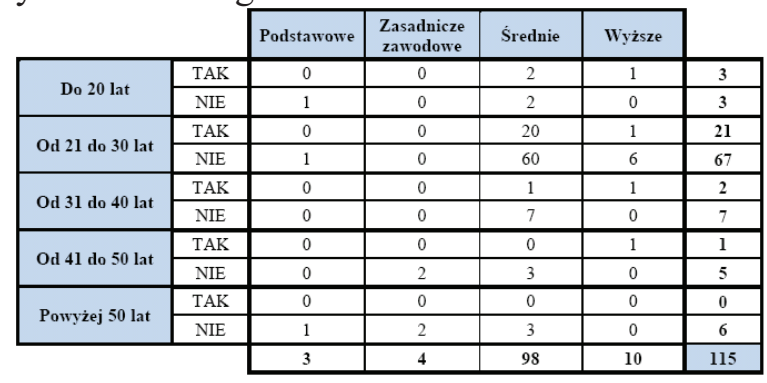

Rysunek 9: Udziat ankietowanych $w$ kursach elearning.

Jedna czwarta ankietowanych brała udział w kursach prowadzonych $\mathrm{w}$ formie e-learning, większość $\mathrm{z}$ nich to osoby $\mathrm{W}$ przedziale wiekowym od 21 do 30 lat ze średnim wykształceniem (Rysunek 9).

\section{Zakończenie}

W ramach przeprowadzonego badania ankietowego na temat edukacji na odległość zebrano materiał obejmujący 115 kwestionariuszy. Ankieta posiadała formę papierową, a dane zawarte $\mathrm{w}$ metryczce pozwoliły na scharakteryzowanie osób objętych badaniem. $\mathrm{Na}$ podstawie wyników badania można wnioskować, że pojęcie e-learning jest znane, ale, pomimo że z tym pojęciem spotkało się $80 \%$ badanych to jednak praktyczna wiedza o nim jest niewielka. Tylko 2,6\% ankietowanych deklaruje, że zna to pojęcie i związane $\mathrm{z}$ nim zagadnienia bardzo dobrze. Około $30 \%$ badanych stwierdza, że pojęcie e-learning jest im znane dobrze. Pozostałej grupie respondentów to zagadnienie jest słabo znane lub w ogóle nic o nim nie wie.

E-learning jest metodą nauczania z wykorzystaniem technik informatycznych. Ponad połowa ankietowanych wzięłaby udział $\mathrm{w}$ zajęciach prowadzonych $\mathrm{w}$ takiej formie, ale mimo to za bardziej efektywny sposób nauczania uważają kształcenie sposobem tradycyjnym lub mieszanym. Najbardziej interesujące dla potencjalnych odbiorców są kursy językowe lub szkolenia podnoszące kwalifikacje.

Analizując wyniki badań nasuwa się wniosek o konieczności rozwijania i promowania międzygeneracyjnej edukacji. $\mathrm{Na}$ podstawie wyników badań można stwierdzić, że nauczanie e-learning jeszcze nie jest powszechnie znane, ale ciekawe szkolenia multimedialne realizowane tą metodą na pewno znajdą swoich zwolenników wśród wszystkich pokoleń. Prowadzone tą metodą zajęcia z zakresu edukacji ekologicznej już od drugiego etapu nauczania w szkołach, dzięki swej dostępności mogą stanowić znakomite uzupełnienie treści przekazywanych przez nauczyciela w tradycyjnej formie. Również rodzice i dziadkowie coraz powszechniej korzystający z Internetu mogą podnieść swoje kwalifikacje.

Chociaż opracowanie kursu e-learning jest zadaniem pracochłonnym i czasochłonnym, istnieje duża szansa, że mimo braku pełnego zaufania do metod nauki elektronicznej, wielu uczniów i spora część dorosłych respondentów wzięłaby udział w kursie o żywotnej problematyce ekologicznej, najchętniej w kursie czy szkoleniu formalnie podnoszącym kwalifikacje.

\section{Literatura}

[1] BOŁTROMIUK, A. Polacy w zwierciadle ekologicznym (online). [cit. 2010-01-29]. URL $<$ http://www.cbos.pl/SPISKOM.POL/2000/K_16 $100 . \mathrm{PDF}>$

[2] DEPEŠOVÁ, J. - ŠIRKA, J. Tradičné technologie a ich využiti $\mathrm{v}$ ergoterapii. In Zborník Technické vzdelanie ako súčast' 
všeobecného vzdelania. B. Bystrica: FPV UMB, 2003. s. 409 - 413. ISBN 80-8055-870-1.

[3] KAŠŠÁKOVÁ, V.- KOZIK,T. Secondary school education and its relation to students successfulness and interest in study at technical universities In Technické vzdelávanie v informačnej spoločnosti. Nitra UKF, 2004 s. 130 - 152. ISBN 80-8050-745-7

[4] KOMOROWSKA, K. A. Ekologiczna świadomość Polaków (online). [cit. 2010-01-29]. URL $<$ http://www.ineisd.org.pl/obrazki/file/ekoherkules/Swiadomosc ekologiczna Polakow InE-2008.pdf >.

[5] NOGA, H. Wybrane aspekty edukacji informatycznej dzieci i młodzieży. In Technika Informatyka-Edukacja. Teoretyczne i praktyczne podstawy edukacji informatycznej, tom VI, [w.]
Roczniki Dydaktyczne U Rz, 2006 s. 111-116. ISBN 83-88845-70-5.

[6] TOMKOVÁ, V. - VARGOVÁ, M Mimoškolská technická záujmová činnost'. In Technické vzdelávanie $\mathrm{v}$ informačnej spoločnosti. Nitra: PF UKF. 2004. s. 341-350. ISBN 80-8050-745-7. EAN 9788080507459.

Dr inż. Krzysztof Pytel

Instytut Techniki

Uniwersytet Pedagogiczny im. KEN

ul. Podchorążych 2

30-084 Kraków, PL

tel. +48126382521, fax +48126382521

e-mail: kpytel@ap.krakow.pl

Www pracovišstě: www.up.krakow.pl 